Analisis Pengaruh Kepercayaan Diri ... (Sungadi)

\title{
ANALISIS PENGARUH KEPERCAYAAN DIRI TERHADAP PENGEMBANGAN PROFESI PUSTAKAWAN UII
}

\author{
Sungadi \\ Pustakawan Universwitas Islam Indonesia \\ sungadi@uii.ac.id
}

\begin{abstract}
Riset ini menganalisis tentang kepercayaan diri pustakawan Universitas Islam Indonesia (UII) dalam menjalani profesinya. Subjek penelitian ini adalah pustakawan UII sebanyak 27 orang yang berada di berbagai unit kerja antara lain: di Direktorat Perpustakaan UII, Fakultas Ekonomi UII dan Fakultas Hukum UII. Selama ini profesi pustakawan masih dianggap sebagai profesi kelas dua oleh sebagian masyarakat, sementara itu bagi pustakawan sendiri masih ada sebagian kecil pustakawan yang belum "bangga" dengan profesinya. Dengan penelitian ini, akan diketahui seberapa besar/tinggi kepercayaan diri pustakawan UII dalam statusnya sebagai pustakawan. Hasil riset memberikan gambaran bahwa tingkat kepercayaan diri pustakawan UII dalam menjalani profesi pustakawan berada pada posisi tinggi sebesar $68 \%$. Tingkat pengembangan karir pustakawan UII berada pada posisi tingkat sedang sebesar 50\%. Berdasarkan hasil uji korelasi, dalam penelitian dapat disimpulkan bahwa dalam riset ini menolak hiphotesis yang menyebutkan bahwa terdapat pengaruh antara kepercayaan diri dengan pengembangan profesi pustakawan UII dalam menjalani profesinya. Tingkat korelasi antara kepercayaan diri dengan pengembangan profesi pustakawan UII adalah sebesar 30\% (0,300). Artinya pengaruh pengembangan karir pustakawan dari kepercayaan diri hanya sebesar 30\% saja, sementara masih ada faktor di luar kepercayaan diri sebesar 70\% yang mempengaruhi pengembangan karir pustakawan. Faktor lain di luar kepercayaan diri tersebut antara lain: (1) adanya tugas ganda bagi pustakawan sehingga pekerjaan kepustakawanan hampir tidak tersentuh; (2) adanya program pelatihan dan peningkatan pendidikan yang lebih tinggi bagi pustakawan di bidang kepustakawanan; (3) adanya motivasi yang tinggi bagi pustakawan juga dapat mempengaruhi peningkatan profesi pustakawan; (4) lingkungan kerja yang kondusif; dan (5) adanya kepemimpinan profetik yang diberlakukan di lembaga dimana pustakawan mengembangkan profesinya.

Kata kunci: kepercayaan diri, pustakawan, profesi
\end{abstract}

\section{Pendahuluan}

\section{Latar Belakang Masalah}

Pegawai Perpustakaan Universitas Islam Indonesia (UII) telah diakui sebagai pejabat fungsional pustakawan sejak tahun 1993 melalui inpassing. Dalam perjalanannya banyak ditemui kendala antara lain rendahnya pendidikan mulai dari tingkat pendidikan pustakawan yang rendah, pangkat dan golongan, tim penilai angka kredit pustakakawan, pemahaman butir-butir kegiatan, tata cara menyusun Daftar Usul Penetapan Angka Kredit (DUPAK), dan lainnya. Pendidikan para pustakawan UII saat itu hanya berijazah SLTA dan sederajat, sementara syarat minimal untuk menjadi pustakawan harus berpendidikan Diploma 2 bidang perpustakaan atau diploma 2 bidang lain yang telah disetarakan. Pada tahun 1993 pangkat dan golongan pegawai perpustakaan UII paling tinggi golongan II/c. Di satu sisi diperlukan tim penilai. Saat itu di UII belum memiliki pustakawan yang memiliki syarat sebagai tim penilai. Untuk mengisi kekosongan ini, maka diangkat tim penilai dari perguruan tinggi lain yang masih berlangsung sampai sekarang. Sementara untuk memberikan bekal pengetahuan terhadap butir-butir kegiatan pustakawan dan tata cara penyusunan DUPAK telah banyak dilakukan diklat dan workshop. Untuk mengembangkan karirnya dalam menjalani profesi sebagai pustakawan, saat ini pustakawan UII diberikan kesempatan untuk menempuh pendidikan formal sampai dengan pada jenjang Srata 3 (S3/doktor). Hal ini sebagaimana diatur pada Peraturan Universitas Islam Indonesia Nomor 13 tahun 2014 tentang Tugas Belajar bagi Tenaga Kependidikan Tetap Universitas Islam Indonesia. 
Masyarakat saat ini terutama masyarakat yang banyak berinteraksi dengan dunia kepustakawanan telah mulai mengenal bahwa pustakawan sebagai profesi. Hal ini dibuktikan dengan semakin banyaknya media masa di Indonesia baik tercetak maupun elektronik yang mengeksplor dunia kepustakawanan. Profesi pustakawan dari waktu ke waktu semakin menampakkan sinarnya dengan adanya pengakuan pemerintah terhadap Profesi Pustakawan dengan terbitnya Surat Keputusan (SK) Menpan dan Reformasi Birokrasi terbaru Nomor 9 Tahun 2014 tentang Jabatan Fungsional Pustakawan dan Angka Kreditnya. Surat Keputusan ini merupakan jalan mudah bagi pustakawan untuk membuktikan potensi dirinya bahwa memang profesi pustakawan pantas untuk memperoleh apresiasi.

Agar dapat menjalani profesinya dengan baik sebagai pejabat fungsional pustakawan diperlukan skill khusus yang didapat melalui studi formal, nonformal, dan atau informal, maka semakin tinggi jabatan bagi pustakawan maka semakin tinggi pula skill yang dapat ia kontribusikan dalam upaya memajukan dunia kepustakawanan. Apabila melihat ke belakang, di masa dulu ada anggapan bahwa ketika ada pegawai di luar perpustakaan dipindahkan/dimutasi di unit perpustakaan dia dianggap sebagai pegawai buangan. Ciri dan kesan negatif tersebut akan tertanam dalam pikiran mereka sehingga perpustakaan dianggap sebagai tempat orang-orang buangan, dan tempat orangorang putus asa sehingga secara mental ada rasa ketidaknyamanan di dalam diri mereka. Hal ini akan menyebabkan kinerja mereka kurang maksimal, dan pelayanan prima pun jauh dari harapan, maka cara ini akan menghasilkan untuk menghasilkan pelayanan yang kurang memuaskan.

Profesi Pustakawan memiliki beberapa kelebihan apabila dibandingkan dengan pegawai administrasi non fungsional, antara lain: (1) kenaikan jabatan dan pangkat dapat dicapai dalam
2 (dua) tahun, sementara pegawai administrasi non pustakawan dapat diraih dalam waktu 4 (empat) tahun; (2) pustakawan mendapat tunjangan fungsional setiap bulan, pegawai administrasi non pustakawan tidak mendapatkan; (3) usia pensiun pustakawan 60-65 tahun, pegawai administrasi non pustakawan pensiun pada usia 55 tahun.

Namun demikian masih ada pustakawan yang tidak bangga dengan profesinya, dan masih malu menyebut identitas dirinya sebagai pustakawan. Profesi pustakawan masih dipandang sebagai profesi kuno oleh sebagian masyarakat. Profesi pustakawan masih dianggap profesi kelas dua.

Indikator masih adanya kepercayaan diri yang rendah bagi pustakawan UII adalah adanya beberapa pustakawan yang dinonaktifkan sementara dari jabatan fungsional pustakawan karena tidak mampu mengajukan PAK (Pengajuan Angka Kredit) yang diperlukan. Data di lapangan membuktikan bahwa dalam jangka 4 (empat) tahun terakhir, ada 44\% pustakawan yang diberhentikan sementara dari jabatan fungsionalnya.

Berangkat dari permasalahan tersebut, peneliti tertarik untuk meneliti lebih lanjut terkait dengan tingkat kepercayaan diri pustakawan UII Yogyakarta.

\section{Rumusan Masalah}

Berangkat dari latar belakang di atas, peneliti mengambil obyek riset pada tingkat kepercayaan diri pustakawan UII dalam menjalani profesinya. Oleh karena itu permasalahan dalam studi ini ialah: adakah pengaruh kepercayaan diri pustakawan terhadap pengembangan profesi pustakawan UII dalam menjalani profesinya?

\section{Tujuan}

Atas dasar permasalahan tersebut, riset ini bertujuan untuk menganalisis dan membuktikan adakah pengaruh kepercayaan diri pustakawan terhadap pengembangan profesi pustakawan UII 
Analisis Pengaruh Kepercayaan Diri ... (Sungadi)

dalam menjalani profesinya. Selain itu studi ini bertujuan untuk menganalisis dan mengetahui seberapa besar tingkat kepercayaan diri dalam pengembangan profesi pustakawan UII.

\section{Manfaat}

Penelitian ini diharapkan dapat berkontribusi antara lain:

1. Secara empiris membuktikan seberapa besarkah tingkat kepercayaan diri pustakawan UII dalam menjalani profesinya.

2. Dapat digunakan sebagai bahan rujukan bagi pustakawan UII dalam upaya meningkatkan kepercayaan dirinya pada saat menjalani profesinya sebagai pustakawan, sehingga ada perasaan bangga sebagai pustakawan UII.

3. Sebagai rujukan bagi peneliti selanjutnya pada topik yang sama dalam menjalani profesinya sebagai pustakawan.

\section{Hipotesis}

Terdapat pengaruh yang signifikan antara kepercayaan diri terhadap pengembangan profesi Pustakawan Universitas Islam Indonesia.

\section{Landasan Teori}

\section{Pustakawan}

Undang-Undang Republik Indonesia No.43 Tahun 2007 tentang Perpustakaan dalam pasal 1 ayat 8 menjelaskan, bahwa "Pustakawan adalah seseorang yang memiliki kompetensi yang diperoleh melalui pendidikan dan/ atau pelatihan kepustakawan dan serta mempunyai tugas dan tanggung jawab untuk melaksanakan pengelolaan dan pelayanan perpustakaan". Pengertian lain mengatakan bahwa: Pustakawan adalah pegawai negeri sipil yang berpendidikan pada bidang ilmu perpustakaan yang mendapatkan tugas melaksanakan aktivitas kepustakawanan pada unit perpustakaan milik pemerintah maupun swasta dan lembaga informasi lainnya (Soeatminah, 2002:161). Menurut Keputusan Menteri Pendayagunaan Aparatur Negara Nomor 132/KEP/M.PAN/12/2002 tentang Jabatan Fungsional Pustakawan Dan Angka Kreditnya menyatakan bahwa : Pustakawan adalah Pegawai Negeri Sipil atau Pegawai Swasta yang bersatus sebagai Pejabat Fungsional Pustakawan yang mendapatkan tugas melaksanakan aktivitas kepustakawanan pada unit perpustakaan milik pemerintah maupun swasta dan lembaga informasi lainnya.

Sementara Sulistyo-Basuki (2010), menjelaskan bahwa, Pustakawan ialah pejabat yang menjalankan tugas kepustakawanan di perpustakaan atau lembaga informasi lainnya dengan bekal pendidikan formal ataupun non formal pada bidang ilmu perpustakaan.

Dari pengertian di atas dapat dipahami bahwa pustakawan adalah pegawai negeri sipil atau swasta yang melaksanakan tugas kepustakawanan di perpustakaan pemerintah dan swasta atau lembaga informasi lainnya atas dasar pendidikan pada bidang ilmu perpustakaan dan informasi yang diperolehnya.

Permenpan Nomor 9 tahun 2014 ab 1 Pasal 1 menjelaskan bahwa, Profesi Pustakawan adalah tugas yang memiliki luasan subjek yang tercakup, fungsi, wewenang, dan tanggungjawab, serta hak untuk menjalankan tugas kegiatan di bidang perpustakaan, dokumentasi, dan informasi (perpusdokinfo).

Profesi pustakawan merupakan bagian dari 114 jabatan fungsional tertentu. Jabatan fungsional pustakawan adalah jenjang karir yang hanya dapat dimiliki oleh seseorang yang telah memiliki status sebagai pejabatnegerisipil/swastayangmempunyai keahlian di bidang kepustakawanan lewat pendidikan berstrata, nonformal, atau informal. Keberadaan Jabfung Pustakawan Indonesia mulai diakui oleh Pemerintah RI pada tahun 1988 melalui KEPMENPAN No. 18 Tahun 1988, kemudian 
diperbarui dengan KEPMENPAN No. 33 Tahun 1998, dilanjut revisi menjadi KEPMENPAN Nomor 132/ KEP/M.PAN/12/2002, dan terakhir direvisi dengan PERMENPAN No. 9/2014 tentang Jabatan Fungsional Pustakawan dan Angka Kreditnya. Jenjang profesi pustakawan berdasarkan PERMENPAN No. 9 tahun 2014 terdiri atas pustakawan keterampilan (tenaga teknis perpustakaan) dan pustakawan keahlian. Yang membedakan kedua tingkatan tersebut adalah dilihat dari latar belakang pendidikan masing-masing pada saat pengangkatan pertama kali menjadi pustakawan. Pustakawan terampil berpendidikan D2/D3 bidang ilmu perpustakaan atau bidang lain yang telah disetarakan. Sementara pustakawan tingkat ahli adalah mereka yang berpendidikan minimal S1 ilmu perpustakaan atau ilmu lain yang sudah disesuaikan. Saat ini jumlah jabatan fungsional pustakawan yang terdaftar dalam bank data Pusat Pengembangan Pustakawan Perpustakaan Nasional RI pada bulan Desember 2016 berjumlah 2919 orang terdiri dari 1106 pustakawan keterampilan dan 1813 pustakawan keahlian. Pada pangkalan data tersebut tampak bahwa jumlah pustakawan tingkat terampil sebanyak (38\%), pustakawan tingkat ahli sebanyak (62\%). Hal ini menggambarkan bahwa jumlah pustakawan tingkat terampil lebih sedikit dibandingkan dengan tingkat ahli. Kondisi ini menunjukkan bahwa (38\%) kualifikasi pustakawan masih pada taraf teknisi atau penunjang profesional belum pada tahap profesional. Upaya peningkatan kualitas pustakawan untuk menjadi profesional (pustakawan terampil menjadi pustakawan ahli) salah satu cara yang dapat dilakukan adalah dengan cara menempuh pendidikan S1 ilmu perpustakaan atau ke tingkat strata yang lebih tinggi lagi (S2) S3). Hal inilah yang menjadi salah satu kendala bagi pustakawan untuk mengembangkan karirnya, terutama pada butir kegiatan pengembangan profesi (misalnya kesulitan dalam membuat karya tulis ilmiah, melakukan penelitian, dan pengkajian perpustakaan). Menurut Mallawa (2016) peningkatan karier pustakawan sangat banyak ditentukan oleh kemampuan individual dan kemandiriannya. Dalam pengembangan karir pustakawan mempunyai peluang untuk mencapai pangkat dan jabatan tertinggi, sepanjang pustakawan yang bersangkutan dapat memenuhi angka kredit serta peraturan lainnya yang telah ditetapkan. Karier pustakawan juga sangat ditentukan oleh pustakawan itu sendiri, oleh karena itu setiap pustakawan harus berusaha semaksimal mungkin untuk meningkatkan profesionalitasnya dalam bidang kepustakawanan baik melalui pendidikan formal maupun non-formal.

Ditengah-tengah dunia kepustakawanan Indonesia, saat ini dikenal dengan pustakawan inpassing dan pustakawan alih jalur dari non pustakawan. Inpassing jabatan/pangkat pustakawan adalah proses penyetaraan kepangkatan, golongan, dan jabatan fungsional pustakawan. Kecuali penyetaraan kepangkatan, golongan, dan jabatan fungsional juga terdapat skor angka kredit yang diberikan bagi calon pustakawan inpassing. Misalnya menurut UII (1993) inpassing pangkat golongan/ruang II/c diberikan angka kredit 75, sehingga untuk kenaikan ke II/d pustakawan yang bersangkutan memerlukan angka kredit 5 . Contoh lain calon pustakawan inpassing golongan II/a diberikan angka kredit 32.5, dengan demikian mereka butuh angka kredit 7,5 untuk dapat naik ke golongan II/b. Sementara pustakawan alih jalur dari non pustakawan mekanismenya menurut Perpusnas RI (2015) adalah bahwa pengangkatan calon pustakawan alih jalur dari tugas struktural atau tugas fungsional lain dalam Profesi Pustakawan, diperlukan syarat sebagai berikut:

1. berpendidikan minimal D2 di bidang kepustakawanan dari lembaga pendidikan tinggi yang terakreditasi; atau berpendidikan D2 bidang lain dari lembaga pendidikan tinggi yang terakreditasi, ditambah mengikuti 
dan lulus Pendidikan Kilat Profesi Pustakawan tingkat Terampil bagi Profesi Pustakawan Terampil; atau

2. berpendidikan minimal S1 Bidang Kepustakawanan dari universitas/sekolah tinggi/akademi yang terakreditasi; atau berpendidikan minimal S1/D4 bidang lain dari universitas/sekolah tinggi yang terakreditasi, ditambah mengikuti dan lulus Pendidikan Kilat Profesi Pustakawan tingkat Ahli bagi Profesi Pustakawan Ahli.

3. mempunyai pengalaman pekerjaan di bidang perpustakaan, dokumentasi, dan informasi (perpusdokinfo) minimal 1 (satu) tahun secara berurutan;

4. berumur maksimal 53 tahun pada saat diangkat sebagai pejabat fungsional pustakawan;

5. terdapat lowongan untuk profesi pustakawan;

6. memiliki kinerja minimal dengan nilai baik pada 2 tahun terakhir;

7. pangkat yang diberikan sama dengan pangkat yang dipunyai dan tingkat jabatan diberikan sesuai dengan besaran angka kredit yang ditentukan oleh petugas yang berwenang menentukan angka kredit;

8. besaran angka kredit ditentukan dari unsur utama dan unsur penunjang.

Dari uraian tersebut dapat dianalisis bahwa dari segi kemampuan/kompetensi keilmuan bagi pustakawan inpassing dan pustakawan alih jalur jelas tampak berbeda jauh dengan pustakawan yang memiliki latar belakang pendidikan ilmu perpustakaan. Sebagai ilustrasi diambil salah satu bidang kegiatan mendasar misalnya pekerjaan klasifikasi/katalogisasi. Kegiatan ini di bangku kuliah pada prodi D3/S1 Ilmu Perpustakaan diajarkan/ditempuh dalam dua (2) semester. Sementara bagi pustakawan inpassing/alih jalur hanya mendapat muatan pelajaran dalam dua (2) bulan untuk seluruh mata pelajaran ilmu dasar perpustakaan, yang meliputi: katalogisasi, klasifikasi, pengembangan koleksi, pelayanan pemakai, perawatan bahan pustaka, dll. Hal ini dapat dibayangkan betapa beratnya untuk dapat menyerap ilmu yang seharusnya ditempuh dalam tujuh sampai dengan delapan semester (minimal beban SKS 144). Sementara bagi pustakawan yang disetarakan dari beban mata kuliah sebesar 144 SKS hanya ditempuh dalam waktu dua bulan melalui diklat CPTA (Calon Pustakawan Ahli) atau CPTT (Calon Pustakawan Terampil). Maka tidaklah heran, bagi sebagian pustakawan yang disetarakan mengalami banyak kendala pada saat menjalani tugas fungsionalnya.

Lebih lanjut menurut Permenpan dan Reformasi Birokrasi RI (2014) dapat dijelaskan bahwa, yang disebut dengan Profesi Pustakawan adalah tugas yang memiliki wilayah kerja, fungsi, tanggungjawab, kewenangan, dan hak untuk melakukan aktivitas di bidang perpusdokinfo. Kegiatan kepustakawan ini terdiri dari: pendidikan, pengorganisasian seluruh sumber daya perpustakaan, dan mengembangkan sistem kepustakawanan, dan mengembangkan profesi kepustakawanan. Sebagaimana telah dijelaskan di atas bahwa, saat ini di Indonesia dikenal dengan istilah pustakawan keterampilan dan pustakawan keahlian pada setiap jenjang mempunyai tugas pokok yang berbeda, antara lain sebagai berikut:

1. Butir kegiatan Pustakawan Keterampilan, meliputi:
a. Pengorganisasian Sumber Daya
Perpustakaan, meliputi:
merencanakan pelaksanaan kegiatan
perpustakaan; (2) memantau dan mengevaluasi pelaksanaan pekerjaan perpustakaan.
b. Layanan Perpustakaan, meliputi: layanan teknis; (2) layanan pemakai
c. Pengembangan Sistem Kepustakawanan: Pengembangan kepustakawanan


d. Pengembangan Profesi Pustakawan

2. Butir kegiatan Pustakawan Keahlian, terdiri dari:

b. Layanan Perpustakaan, meliputi: (1) layanan teknis (pelayanan yang tidak berhubungan langsung dengan pemustaka: pengembangan koleksi, pemrosesan koleksi perpustakaan, dan pemeliharaan bahan pustaka); (2) pelayanan pemustaka (pelayanan sirkulasi, pelayanan bahan rujukan/ referensi, pendidikan pemakai/literasi informasi, promosi perpustakaan, dan lain-lain).

c. Pengembangan Sistem Kepustakawanan, meliputi: (1) riset di bidang perpusdokinfo; (2) pengembangan perpusdokinfo; (3) menganalisis/ mengkritisi karya kepustakawanan; (4) menelaah pengembangan sistem perpusdokinfo.

d. Pengembangan Profesi Pustakawan

Berdasarkan paparan di atas dapat dipahami, bahwa sesuatu yang membedakan tugas pokok bagi pustakawan tingkat terampil dan tingkat ahli adalah adanya tugas pengkajian kepustakawanan, menganalisis/mengkritisi karya kepustakawanan, dan penelaahan pengembangan sistem kepustakawanan bagi pustakawan ahli, sementara bagi pustakawan tingkat terampil tidak ada.

Pengorganisasian perpusdokinfo adalah kegiatan yang terdiri merencanakan, memantau, dan mengevaluasi pelaksanaan pekerjaan perpustakaan yang terdiri dari pekerjaan jangka pendek, menengah, dan jangka panjang, serta kegiatan yang bersifat rutin atau pengembangan. Disamping itu pengelolaan dan penyelenggaraan perpustakaan juga dilakukan secara spesifik, terukur, ketercapaian, realistis, dan terjadwal. Monitoring dan evaluasi kegiatan perpustakaan dimaksudkan untuk memonitor dan merekam perkembangan, kadar prestasi maupun kemunduran dengan komitmen yang disepakati, start dari perancangan, implementasi, hingga selesainya aktivitas bagi unit kerja teknis.

Layanan perpusdokinfo adalah aktivitas melakukan pendampingan dan penyuluhan jasa perpusdokinfo terhadap pemakai yang terdiri pelayanan teknis (pelayanan yang tidak terkait langsung dengan pemustaka: pengembangan koleksi, pemrosesan koleksi perpustakaan, dan pemeliharaan bahan pustaka) dan pelayanan pemustaka (terdiri dari pelayanan sirkulasi, pelayanan bahan rujukan/referensi, pendidikan pemakai/literasi informasi, promosi perpustakaan, dan lain-lain).

Pengembangan sistem kepustakawanan adalah pekerjaan untuk mendayagunakan tingkat kinerja perpustakaan secara empiris dan profesional, sehingga didapat prosedur kerja yang maksimal, efektif dan efisien dalam upaya untuk meraih layanan prima bagi pemustaka. Sementara yang dimaksud dengan pekerjaan meningkatkan sistem kepustakawanan adalah aktivitas yang terdiri atas riset pada bidang kepustakawanan, pengembangan kepustakawanan, menganalisis kinerja kepustakawanan, dan menelaah pengembangan sistem perpusdokinfo.

Riset perpusdokinfo adalah penelitian yang dilaksanakan secara sistematis pada bidang perpusdokinfo disandarkan pada analisis kuantitatif atau kualitatif atau gabungan keduanya yang mengacu dari desain dan metodologi penelitian. Riset dimaksudkan untuk memutuskan dalam problem solving dan meningkatkan prestasi kerja 
kepustakawanan serta dijadikan referensi dalam mengembangkan ilmu pengetahuan di bidang perpusdokinfo. Hasil penelitian didiseminasikan pada seminar/lokakarya dan dapat dipublikasikan pada jurnal dan penerbitan ilmiah perpusdokinfo.

Penganalisisan karya kepustakawanan adalah kegiatan membaca, menilai karya kepustakawanan dari pustakawan lain berupa kertas atau elektronik. Dari hasil penilaian tersebut dirangkum dalam bentuk tulisan baru berupa ulasan/kritik/saran/ tanggapan secara sistematis.

Lebih lanjut kegiatan penelaahan pengembangan sistem kepustakawanan adalah pekerjaan membuat karya tulis ilmiah, luas, strategik tentang proposal kegiatan ilmiah, kegiatan ini juga termasuk masukan dan saran yang bersifat kritikan terhadap implementasi tata tertib, kebijakan strategis, program kerja kepustakawanan dari berbagai lembaga informasi termasuk di dalamnya perpustakaan dan memberikan alternatif jalan keluar dan pemecahan persoalan (problem solving) untuk pengembangan dan kejayaan perpusdokinfo. Hasil penelaahan didiseminasikan pada pertemuan ilmiah dan dapat dipublikasikan pada jurnal dan penerbitan ilmiah perpusdokinfo.

Pengembangan profesi ialah upaya meningkatkan pengetahuan, keahlian, minat dan bakat yang memberi kemanfaatan bagi pejabat pustakawan dalam menjalankan profesi kepustakawanan. Pengembangan profesi merupakan butir kegiatan utama yang ditetapkan nilai kreditnya, terdiri atas sub butir kegiatan: membuat artikel ilmiah di bidang perpusdokinfo; menerjemahkan/menyadur dokumen berupa buku dan/atau tulisan lain di bidang perpusdokinfo; dan membuat buku acuan/manual/acuan teknis. Unsur pekerjaan pustakawan selengkapnya adalah meliputi: Pendidikan, terdiri dari: 1) pendidikan formal berstrata yang mendapatkan gelar dan surat tanda tamat belajar (STTB)/ ijazah; 2) pendidikan kilat profesi pustakawan mendapat surat keterangan lulus atau sertifikat; dan 3) Diklat Prajabatan. Kegiatan lainnya adalah mengorganisasikan perpustakaan yang meliputi: perancangan kegiatan perpustakaan; memantau dan evaluasi atas penyelenggaraan perpustakaan; dan pelayanan perpustakaan (pelayanan teknis dan pelayanan pengguna).

Pengembangan Sistem Perpusdokinfo (meningkatkan kinerja perpustakaan secara ilmiah dan profesional), meliputi: 1) pengkajian Kepustakawanan; 2) pengembangan Perpusdokinfo (membimbing dan memberikan konsultasi di bidang perpusdokinfo yang berupa konsep, 3) membangun jejaring nasional/internasional); 4) melakukan analisis dan mengkritisi karya perpusdokinfo; dan 5) melakukan telaah terhadap pengembangan sistem perpusdokinfo (membuat artikel ilmiah berisikan masukan, kritik dan saran atau pertimbangan terhadap pelaksanaan peraturan, kebijakan, program, atau mekanisme kepustakawanan).

Pengembangan profesi meliputi: 1) menulis buku atau artikel ilmiah di bidang perpusdokinfo; 2) menerjemahkan/menyadur karya tulis di bidang perpusdokinfo; 3) membuat Buku Acuan (manual), 4) Kegiatan Acara Perpusdokinfo, 5) memimpin sebuah unit perpusdokinfo atau komunitas kepustakawanan.

Unsur Penunjang meliputi: 1) Pengajar/Pelatih; 2) Peran serta dalam Pertemuan Ilmiah; 3) Menjadi Anggota Profesi IPI (Ikatan Pustakawan Indonesia di tingkat Nasional atau Daerah; 4) Menjadi Tim Penilai Daftar Usul Angka Kredit (DUPAK) Pustakawan; 5) Mendapatkan Anugerah/Satya Lencana di bidang perpusdokinfo; 6) Mendapatkan gelar/ijazah pendidikan tinggi formal (S1, S2, dan atau S3) bidang ilmu lainnya di luar perpusdokinfo; 7) Mengikuti lomba; 8) Sebagai editor naskah risalah seminar/ lokakarya/workshop/semiloka dan sejenisnya. 


\section{Kepercayaan Diri}

Pengertian Kepercayaan Diri

Menurut Walgito (1993) kepercayaan diri sebagai bagian dari sifat hakiki yang tercermin pada sikap seseorang yang terbentuk dalam interaksi personal dengan lingkungannya, khususnya lingkungan sosial. Lauster (1978) menyatakan kepercayaan diri adalah kemantapan dan keteguhan hati terhadap diri sendiri sehingga ia tidak mudah kena bujukan dari pihak lain. Orang yang percaya diri menurutnya tidak perlu dorongan dari orang lain, tidak egois dan oportunis, penuh tenggang rasa, mampu mengendalikan diri dan tidak ambisius, penuh dengan kesederhaan, optimisitk, menyelesaikan pekerjaan dengan efisien dan penuh tanggung jawab, gembira, periang dan humoris, tingkat semangat yang tinggi, inisiatif, dan merasa aman. Pendapat ini diperkuat oleh Redenbach (Raudhah, 1998), yang menyebutkan bahwa kepercayaan diri adalah kemampuan secara psikis untuk menanggulangi efek jahat dari sifat ragu.

Kepercayaan memberikan pengertian kepercayaan diri sebagai keyakinan terhadap potensi dirinya, skill, keterampilan dan kemampuan untuk menyelesaikan tugas/pekerjaan secara sukses dengan penuh kepercayaan diri dan yakin bahwa ia mampu dengan hasil karyanya. De Angelis (1997) menganalisis kepercayaan diri menjadi tiga jenis percaya diri yang cukup berbeda, yaitu : (1) Kepercayaan diri yang berkenaan dengan perilaku, yaitu keyakinan diri untuk mampu berlaku dan melaksanakan pekerjaan yang sederhana. (2) Keyakinan diri yang berkaitan dengan emosi, yaitu keyakinan diri seseorang untuk yakin dan mampu mengendalikan segenap sisi emosi. (3) Keyakinan diri yang bersifat spiritual, merupakan kepercayaan diri yang paling penting diantara ketiga macam kepercayaan diri tersebut. Kepercayaan diri yang berkaitan dengan spiritual ini merupakan keyakinan akan kepastian baik/buruk dari Sang Pencipta (takdir) alam semesta, percaya bahwa hidup ini mempunyai tujuan yang mulia, bahwa eksistensi individu tersebut memiliki arti. Tanpa keyakinan diri berketuhanan ini, tidak mungkin kedua jenis keyakinan diri yang lainnya berkembang.

Lindenfield (Raudhah, 2002) menganalisis kepercayaan diri menjadi 2 macam kepercayaan diri yang berbeda, yaitu kepercayaan diri batin dan kepercayaan diri lahir. Jenis kepercayaan diri batin merupakan jenis kepercayan diri yang memberikan perasaan dan anggapan bahwa seseorang dalam keadaan baik. Sementara kepercayaan diri lahir merupakan kepercayaan diri yang memungkinkan seseorang tersebut untuk tampil dan berperilaku dengan cara yang menunjukkan kapada dunia luar bahwa ia yakin akan dirinya. Kedua jenis kepercayaan diri, kepercayaan diri batin dan kepercayaan diri lahir ini saling mendukung.

Berdasarkan berbagai pendapat di atas, maka dapat disimpulkan bahwa kepercayaan diri merupakan keyakinan yang tumbuh dari dalam diri seorang individu setelah ia melakukan interpretasi terhadap kemampuan yang dimiliki. Keyakinan yang tumbuh tersebut akan menimbulkan suatu kemauan yang keras untuk mencapai apa yang diharapkan.

\section{Aspek-aspek kepercayaan diri}

Lugo dan Hersey (Murniatiek, 2001) menyebutkan bahwa orang yang memiliki kepercayaan diri yang tinggi adalah orang yang mau bekerja keras dalam menghadapi tantangan, tidak ragu-ragu, dan kreatif. Kepercayaan diri tersebut dapat menimbulkan rasa aman, dan mengurangi perasaan cemas yang muncul pada saat situasi kurang menyenangkan. Weinberg dan Gould (Andriyani, 2001) menyebutkan bahwa orang-orang yang memiliki kepercayaan diri tinggi lebih mudah mengendalikan dirinya di dalam suatu keadaan yang menekan. Orang tersebut dapat menguasai dirinya untuk bertindak tenang dan 
dapat menentukan saat yang tepat untuk bertindak. Lauster (1978) menyatakan bahwa kepercayaan diri menyebabkan kehati-hatian, tidak mementingkan diri sendiri, toleran, dan mempunyai ambisi yang wajar yang didasarkan pada pemahaman terhadap kemampuannya. Yoder dan Proctor (Yusni, 2002) menyebutkan bahwa individu yang percaya diri adalah mereka yang mampu bersikap asertif serta mempunyai ketekunan dalam menyelesaikan tugas, dapat menerima kekalahan dan penolakan serta membawa kembali suasana hati pada kondisi yang normal secara tepat. Dilihat dari segi sosial, individu yang percaya diri mudah berfungsi sebagai bagian dari kelompok serta dapat bekerja sama dengan orang lain dalam kelompok dan mengambil peran sebagai pemimpin tanpa ragu-ragu jika diperlukan.

Brennecke dan Amich (Andriyani, 2001) berpendapat bahwa orang-orang yang percaya diri berani mencoba hal-hal yang baru yang mungkin berguna untuk lebih mengembangkan diri dan lingkungannya dibandingkan dengan kondisi sebelumnya. Orang yang percaya diri yakin akan kemampuan dirinya, mandiri, ambisi, berani berpendapat, berani mencoba hal-hal yang baru, serta merasa dapat diterima oleh lingkungannya.

Tanda-tanda orang yang tidak yakin terhdap dirinya adalah, kurang bisa menghargai dan menerima diri sendiri setara dengan pihak lain, merasa ada halangan dengan berbagai persoalan, punya perasaan banyak kelemahan diri, kesepian, stres dan kurang bahagia, sulit berinteraksi dengan pihak lain, takut gagal, perasaan minder terhadap pihak lain, dan canggung.

Lauster (1978) menyatakan bahwa orang yang kurang percaya diri cenderung merasa ragu-ragu, kurang bertanggung jawab, merasa malu, kebingungan, merasa dirinya rendah dan kurang percaya diri, kemasyhuran yang besar, kebutuhan yang berlebihan untuk pamer dan keinginan yang berlebih-lebihan untuk dipuji, dan merasa tidak aman.

Menurut Rakhmat (1985) orang yang tidak percaya diri cenderung sedapat mungkin untuk menghindari situasi komunikasi, karena adanya konsep diri yang negatif dan kurangnya kepercayaan kepada kemampuan sendiri dan juga merasa tidak mampu mengatasi persoalan sehingga cenderung untuk menutup diri dari pergaulan.

Guilford (1959) berpendapat, orang yang kurang percaya diri cenderung egosentrisme, merasa orang lain sedang membicarakannya, merasa tidak senang dan tidak puas dengan statusnya (misalnya ingin menjadi lebih tinggi atau lebih pendek daripada keadaannya saat itu), merasa perlu untuk mengadakan perbaikan, perasaan bersalah, dan menangis pada saat sakit.

Berdasarkan berbagai pendapat di atas, maka dapat disimpulkan bahwa ciri-ciri orang yang memiliki kepercayaan diri yang tinggi adalah mereka yang optimis, mandiri dalam menyelesaikan pekerjaan, mempunyai ambisi untuk maju. Bentuk dari kepercayaan diri tersebut adalah mempunyai dorongan-dorongan, berusaha ingin mencapai sesuatu dengan tetap mempunyai pertimbanganpertimbangan yang bijaksana dan sesuai dengan akal sehat, berani mengemukakan pendapat, berani mencoba hal-hal yang baru. Selain dari itu orang yang punya kepercayaan diri juga mampu menunjukkan keinginan untuk selalu berubah ke arah yang lebih baik, perasaan dapat diterima oleh kelompoknya, baik oleh lingkungan keluarga maupun lingkungan kerjanya sebagai tempat berinteraksi. Sedangkan tanda-tanda orang yang tidak yakin dengan dirinya adalah, punya perasaan apa yang dilakukannya tidak adekuat (tidak cocok/ tidak sesuai), merasa tidak mampu mengatasi persoalan yang dihadapi, merasa ada halangan dalam berbagai persoalan, merasa mempunyai banyak kelemahan, tidak yakin akan dirinya sendiri bahwa dirinya memiliki kelebihan, cenderung ragu-ragu dan kurang bertanggung jawab. Individu 
yang kurang percaya diri juga merasa tidak diterima oleh kelompok atau orang lain, merasa kesepian, tertekan, sulit berinteraksi dengan pihak lain, takut tidak diterima oleh pihak lain, dan dalam mendekati orang lain terlalu ragu-ragu dan terlalu kaku sehingga terlihat formil.

\section{Pembinaan Karir Pustakawan}

Eliot (2007), menyatakan sebagai organisme yang berkembang di lingkungan pendidikan tinggi, slogan "Library is the heart of the university" yang berarti perpustakaan adalah jantungnya perguruan tinggi sudah tidak asing di telinga pembaca. Akan tetapi sejauh mana jantung tersebut selalu dipelihara secara berkesinambungan sering pula terdengar menjadi pertanyaan, terutama oleh pustakawan yang memiliki tugas utama dalam memelihara bagian penting dalam lembaga informasi yang bernama perpustakaan. Pustakawan dengan kemampuan dan profesionalismenya mempunyai tugas yang sangat vital dalam menumbuhkembangkan perpusdokinfo, sehingga kemampuan dan profesionalisme pustakawan perlu terus dibina.

Sudarsono (2010) menjelaskan bahwa Continuing Professional Development (CPD) dapat diterjemahkan sebagai Pengembangan Profesional Berkelanjutan atau Pengembangan Keprofesionalan Berkelanjutan (PKB). Istilah pengembangan profesi dalam jabatan fungsional pustakawan memang telah lama dikenal dengan devinisi: "kegiatan pustakawan dalam rangka pengamalan ilmu pengetahuan dan teknologi serta ketrampilan untuk meningkatkan mutu dan profesionalisme bidang kepustakawanan maupun dalam rangka menghasilkan sesuatu yang bermanfaat bagi peningkatan mutu layanan perpustakaan".

Selanjutnya pengembangan profesi tersebut diuraikan dalam berbagai event terdiri atas: "pembuatan karya tulis ilmiah, melakukan tugas sebagai ketua kelompok, menyusun naskah kumpulan tulisan, memberi konsultasi, menyusun pedoman dan membuat terjemahan/saduran".

Sementara Lynn and Glosiene (2007) menyebutkan definisi Continuing Professional Development (CPD) sebagai berikut: The definition of CPD in the context of a library or information is the process by which the library's professional competence and information specialists are maintained by library (librarian) actors throughout their careers. The fuller definition of CPD is: "A lengthy process of upgrading, updating the skills and competencies of a staff, conducted regularly in training and education services, supported by external programs"

Dari definisi di atas dapat ditarik definisi CPD dalam konteks perpustakaan atau informasi adalah prosesdimanakompetensiprofesional perpustakaan dan spesialis informasi dipertahankan oleh pelaku perpustakaan (pustakawan) di sepanjang karier mereka. Adapun pengertian selengkapnya dari CPD adalah:"Suatu proses panjang dalam meningkatkan kemampuan, memperbarui keterampilan serta kompetensi seorang staf, yang dilakukan secara teratur dalam layanan pelatihan dan pendidikan, yang didukung oleh program eksternal" (Prytherch, 2005) dalam (Sudarsono, 2010).

Dalam konteks profesional yang lebih umum CPD dapat diartikan sebagai: Pemeliharaan berkesinambungan dengan meningkatkan kemampuan dan pengetahuan, skill, keterampilan serta pengembangan kompetensi diri bagi pegawai dalam melaksanakan tugas teknis profesional selama perjalanan karirnya.

Dari definisi di atas dapat dipahami bahwa, jika dibanding dengan definisi CPD yang biasa dipedomani oleh pihak-pihak profesional dunia, maka ketentuan profesi dalam jabatan fungsional pustakawan ternyata sangat sempit. Informasi mengenai implementasi konsep CPD dalam pembinaan profesi pustakawan belum banyak memperoleh perhatian. Hingga sekarang informasi yang berhubungan dengan implementasi konsep 
CPD dalam pengembangan profesi pustakawan masih sedikit dan kurang. Oleh sebab itu perlu dilakukan suatu kajian, tulisan ataupun penelitian tentang implementasi konsep CPD dalam pembinaan profesionalisme pustakawan Indonesia, khususnya pustakawan perpustakaan perguruan tinggi.

IFLA (International Federation of Library Association) menetapkan CPD bertolak dari arsip Unesco Public Library Manifesto. Arsip itu menyebutkan bahwa pustakawan adalah penghantar aktif antara pengguna perpustakaan sumberdaya perpustakaan maupun knowledge yang ada di lembaga-lembaga informasi, termasuk di perpustakaan, sehingga eksistensi pustakawan menjadi sangat strategis. Kualitas penghubung akan memiliki peran penting terhadap transfer sumber bacaan dan pengetahuan. Kemampuan penyaji informasi harus dijaga dan ditingkatkan kemampuannya selaras dengan perkembangan zaman dan kebutuhan pemustaka. Dengan demikian skill dan keterampilan serta kualitas pustakawan senantiasa perlu dikembangkan dan ditingkatkan, sehingga CPD perlu dijalani (Sudarsono, 2010).

Secara garis besar CPD adalah tindakan memaksimalkan kemampuan sebagai profesional, karena dengan CPD pustakawan bisa: (1) mempertahankan dan membina kompetensi dalam kinerja, (2) mampu bersaing dan berkompetisi di pasaran kerja, (3) memiliki komitmen pribadi pada profesi dimasa yang akan datang, dan (4) melepaskan diri dari rasa bosan dan mengantisipasi adanya berbagai hal yang mungkin berubah dengan mengetengahkan tantangan akademis yang baru dan menyemangatkan (Sudarsono, 2010).

CPD adalah pendidikan/tarbiyah yang terprogram serta manifestasi dari karir seorang profesional. CPD tidak sekedar sebagai suplemen dalam berkarya maupun terjadi pada satu tahapan kerja saja, namun harus dilaksanakan secara terencana sepanjang pustakawan meniti karir.

IFLA sebagai institusi dunia dari berbagai perpustakaan dan lembaga informasi secara lugas menetapkan 2 asas dasar CPD, yakni:

1. Pembelajaran sepanjang hayat (long life education) dan pembinaan profesi adalah tanggung jawab bersama antara individu, unit kerja yang mengkaryakan, asosiasi profesi pustakawan, dan pendidikan tinggi ilmu perpustakaan dan informasi.

2. Seluruh ide dan gagasan tentang pegawai/ pustakawan dan etika profesionalisme wajib mengupayakan asuransi akses pustakawan pada kesempatan pembinaan profesi berkesinambungan.

Kualitas seorang staf dipengaruhi oleh berbagai faktor, diantaranya menyangkut atribut pribadi seperti bakat, kecerdasan, komitmen, selain faktor lingkungan yang meliputi ketersediaan dan standar pendidikan, pengembangan profesional berkelanjutan (CPD) dan pembelajaran di tempat kerja. Secara jelas IFLA telah merumuskan pedoman pelaksanaan CPD, menjadi 10 pokok penting antara lain:

1. Riset secara kontinyu atas berbagai keperluan pendidikan bagi praktisi di lapangan.

Kompleksitas permasalahan yang dihadapi pustakawan saat ini menuntut kompetensi pustakawan agar terus dikembangkan. Kebutuhan untuk selalu belajar perlu terus dikaji, termasuk materi apa saja yang harus dipelajari pustakawan.

2. Cakupan yang luas atas sumber pembelajaran formal ataupun non-formal.

Diklat formal sebaiknya diselenggarakan melalui bermacam kemasan dan bentuk yang didesain secara eksklusif dalam upaya memenuhi kebutuhan lapangan, dengan bahan ajar dan kurikulum disinkronkan dengan permintaan pasar.

3. Budaya organisasi dan leadership. 
Meskipun CPD bermula dari niat pribadi pustakawan, namun diperlukan dukungan dari organisasi tempat pustakawan bekerja. Komitmen ini diharapkan berasal dari pucuk pimpinan lembaga yang sadar akan peran penting CPD bagi lembaga.

4. Penyebarluasan informasi atas adanya pembelajaran berkesinambungan.

Tidak jarang pustakawan kurang mengetahui hak dan tanggung jawabnya dalam CPD. Tidak semuanya tahu dimana tersedia kesempatan untuk meningkatkan kemampuan dalam berkarya. Oleh karena itu informasi ini perlu disebarluaskan secara jelas dan tepat.

5. Arsitektur dan komposisi pembelajaran berkesinambungan.

Penyelenggara pembelajaran dan diklat seyogyanya mendesain dengan seksama, yang melingkupi atas: tujuan pendidikan, bahan ajar yang cocok dengan permintaan pasar, seleksi tenaga pendidik baik dari segi pengetahuan maupun skill mengajar, monitoring, evaluasi serta feedback dari mahasiswa.

6. Complete documentation of individual participation.

Lembaga pendidikan seyogyanya mengorganisasikan berkas dan arsip milik para mahasiswa/peserta didik. Disisi lain, mahasiswa wajib mengorganisasikan berkas dan arsip milik pribadinya demi terjaganya pendidikan berkesinambungan bagi mereka. Berkas arsip ini digunakan dalam proses decision-making rekrutmen, kenaikan pangkat, maupun promosi.

7. Provision of institutional support funds.

IFLA memberikan ketegasan penyelenggaran pendidikan wajib menyiapkan dana sekurangkurangnya $0,5 \%$ hingga $1 \%$ dari seluruh biaya lembaga bagi pendidikan berkelanjutan.

8. Time allocation for CPD activities.

Disarankan bahwa organisasi/lembaga kerja seyogyanya menyediakan sekurangkurangnya $10 \%$ waktu kerja pegawai untuk kelonggaran ikut serta lokakarya, konferensi, latihan kerja, dan kegiatan pengajaran lain serta pendidikan non-formal dalam rangka CPD.

9. Evaluation of continuing education and professional development.

Evaluasi perlu diselenggarakan untuk mengukur daya guna tersedianya sarana dengan prestasi yang dicapai pegawai ataupun institusi.

10. A study that examines the level of conformity and success of the CPD program.

Organisasi profesi pustakawan semestinya melaksanakan aktivitas ini, terpenting karena mereka harus menyelenggarakan upaya asuransi/pertanggunan bagi peserta didiknya. Pada abad global saat ini, dimana persaingan pustakawan secara internasional sangat terbuka, hal ini merupakan salah satu faktor yang perlu mendapatkan pertimbangan khusus dalam penyelenggaraan CPD bagi pengembangan profesionalisme pustakawan. Oleh karena itu kompetensi pustakawan yang mampu bertanding di kancah internasional perlu terus ditingkatkan.

\section{Research Methods}

\section{Tempat dan Waktu Penelitian}

Riset diselenggarakan di Universitas Islam Indonesia Yogyakarta. Pemilihan lokasi penelitian ini dengan mempertimbangkan beberapa aspek antara lain: masalah yang diteliti berada di Universitas Islam Indonesia, Peneliti bekerja di Universitas Islam Indonesia, dan dalam rangka efisiensi biaya, waktu dan tenaga. Penelitian dilakukan antara bulan Maret - Juli 2016.

Populasi, Sampel dan Model Penentuan Sampel 
Populasi adalah keseluruhan individu yang merupakan sasaran sesungguhnya dalam penelitian. Menurut Kountur (2003) populasi adalah suatu himpunan keseluruhan dari suatu objek yang menggambarkan perhatian periset. Objek riset bisa berbentuk organisme dan makhluk hidup, bendabenda, sistem, prosedur, fenomena, dan lain-lain.

Dalam penelitian ini yang dimaksud dengan populasi adalah pustakawan yang bertugas di lingkungan UII sebagai subyek penelitian. Dari hasil survei awal yang bersumber dari data kepegawaian UII tahun 2016, diperoleh data bahwa pustakawan UII saat ini sejumlah 27 orang. Peneliti berencana mengambil seluruh populasi (sensus) untuk dijadikan subyek penelitian.

\section{Teknik Pengumpulan Data}

Teknik pengumpulan data dilakukan melalui studi dokumen, yaitu dengan cara menyebarkan kuisioner kepada pustakawan yang bertugas di lingkungan kampus UII.

\section{Teknik Analisis Data}

Sesuai dengan tujuan penelitian, data yang diperoleh dari pengumpulan data akan dianalisis secara deskriptif kuantitatif yaitu dengan memaparkan data-data yang ada sedetail mungkin dengan memvisualiasikan ke dalam sebuah tabel, kemudian dilakukan pembahasan secara keseluruhan sehingga dapat diketahui dan dianalisis, kemudian dapat ditarik suatu kesimpulan dengan melalui beberapa tahapan antara lain:

\section{Scoring}

Merupakan kegiatan memberi score atau nilai sesuai ukuran-ukuran yang telah ditentukan dalam jawaban kuisener. Untuk selanjutnya dalam proses analisis data akan digunakan statistik untuk menyederhanakan data penelitian dengan mencari data terendah dan data tertinggi, kemudian dicari rentangnya, maka lebar dan jumlah interval yang tepat dapat ditetapkan (Riduwan, 2003). Pemberian score dilakukan dengan cara menghitung jumlah jawaban pernyataan/pertanyaan kuisener dari setiap responden. Dari hasil hitungan jawaban kuisener dari responden tersebut, akan ditentukan 3 kategori, antara lain: rendah, sedang, dan atau tinggi. Di bawah ini digambarkan kerangka analisis data:

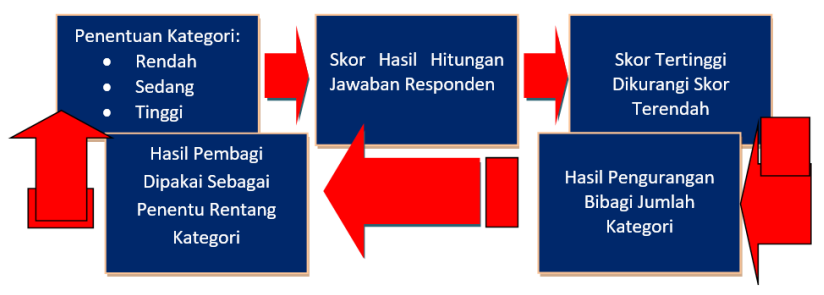

Gambar 1: Kerangka Analisis Data

\section{Tabulasi}

Tabulasi adalah proses memasukkan data pada tabel-tabel tertentu dan mengatur angkaangka serta menghitungnya, sehingga menjadi tabel frekuensi. Rumus persentase dari frekuensi dalam penelitian ini menggunakan:

$$
\begin{aligned}
& \begin{array}{ll}
f & \text { Keterangan: }
\end{array} \\
& \mathrm{N}=\frac{f}{n} x 100 \% \quad \begin{array}{l}
\mathrm{N}=\text { Nilai Hasil } \\
\mathrm{f}=\text { Frekuensi } \\
\mathrm{n}=\text { Jumlah }
\end{array}
\end{aligned}
$$

Gambar 2: Rumus persentase (Singarimbun, 1994)

\section{Hasil Dan Pembahasan}

\section{Temuan Penelitian}

Hasil penelitian yang dilakukan, mendeskripsikan dan menampilkan data dalam bentuk tabel distribusi frekuensi untuk semua variabel yaitu Hubungan Kecemasan Diri dengan Pengembangan Karir Pustakawan. Berikut merupakan uraian analisis dan pembahasan penelitian.

Hasil penelitian dari penyebaran angket sebanyak 27 responden, tetapi tidak kembali 5 angket, sehingga total angket yang dikembalikan 
sebanyak 22. Dari 22 responden tersebut yang mendeskripsikan tingginya Hubungan Kecemasan Diri dengan Pengembangan Karir Pustakawan, diuraikan sebagai berikut.

\section{Gender}

\begin{tabular}{cccc}
\multicolumn{4}{c}{ Tabel 1 Jenis Kelamin Pustakawan UII } \\
\hline No & Gender & Jumlah & Persentase (\%) \\
\hline 1 & Laki-laki & 13 & 59 \\
2 & Perempuan & 9 & 41 \\
& Jumlah & 22 & 100 \\
\hline
\end{tabular}

Sumber: Data Primer $2016 \mathrm{~N}=22$

Tabel 1 menunjukkan bahwa pustakawan UII yang menjadi informan dalam riset ini gender laki-laki sebesar 13 personal (59\%), perempuan sebesar 9 orang (41\%).

\section{Usia}

\begin{tabular}{cccc}
\multicolumn{4}{c}{ Tabel 2 Usia Pustakawan UII } \\
\hline No & Usia (tahun) & Jumlah & Persentase (\%) \\
\hline 1 & Kurang dari 30 & 0 & 0 \\
2 & $31-40$ & 2 & 9 \\
3 & $41-50$ & 9 & 41 \\
4 & Lebih dari 51 & 11 & 50 \\
& Jumlah & 22 & 100 \\
\hline
\end{tabular}

Sumber: Data Primer $2016 \mathrm{~N}=22$

Tabel 2 menunjukkan bahwa pustakawan UII yang menjadi informan dalam riset ini mayoritas berumur lebih 51 tahun sejumlah 11 pustakawan (50\%), usia 41-50 tahun sebesar 9 orang (41\%), berusia antara 31-40 tahun sebesar 2 orang (9\%) dan berusia kurang dari 30 tahun sebanyak 0. Dari tabel 2 ini yang perlu mendapatkan perhatian oleh para pimpinan UII adalah bahwa pustakawan UII saat ini yang telah berusia 55 tahun ke atas ada sejumlah 6 orang, artinya empat samapai lima tahun ke depan pustakawan UII akan berkurang 6 orang. Dan apabila dilihat untuk 10 tahun mendatang, maka pustakawan UII akan berkurang lagi 11 orang.

\section{Pendidikan Terakhir}

Tabel 3 Pendidikan Terakhir Pustakawan UII

\begin{tabular}{cccc}
\hline No & ljazah & Jumlah & Persentase (\%) \\
\hline 1 & SMA dan Sederajat & 7 & 32 \\
2 & D2/D3 & 8 & 36 \\
3 & S1 & 3 & 14 \\
4 & S2 & 4 & 18
\end{tabular}

Sumber: Data Primer $2016 \mathrm{~N}=22$

22

100

Dari tabel 3 tampak bahwa pendidikan terakhir Pustakawan UII Diploma 8 orang (36\%), SLTA 7 orang (32\%), S2 4 orang (18\%) dan S1 3 orang (14\%). Dari data ini apabila mengacu pada Standar Nasional Perpustakaan Perguruan Tinggi, maka dapat tafsirkan bahwa sebesar 68\% terkelompok pada teknis perpustakaan (bukan berstatus sebagai pustakawan) dan hanya 32\% berstatus pustakawan murni. Dan apabila mengacu pada Permenpan Nomor 9 tahun 2014, bahwa saat ini pustakawan UII meliputi: pustakawan keterampilan sebanyak $68 \%$ dan pustakawan keahlian sebanyak 32\%.

\section{Masa Kerja}

\begin{tabular}{cccc}
\multicolumn{5}{c}{ Tabel 4 Masa Kerja Pustakawan UII } \\
\hline No & Masa Kerja (tahun) & Jumlah & Persentase (\%) \\
\hline 1 & $<5$ & 0 & 0 \\
2 & $5-10$ & 0 & 0 \\
3 & $11-15$ & 2 & 9 \\
4 & $16-20$ & 4 & 18 \\
5 & $>21$ & 16 & 73 \\
& Jumlah & 22 & 100 \\
\hline
\end{tabular}

Sumber: Data Primer $2016 \mathrm{~N}=22$

Pada tabel 4 tampak bahwa masa kerja pustakawan UII sebanyak 16 orang (73\%) telah bekerja selama lebih dari 21 tahun, dan masa kerja antara 16-20 tahun sebesar 4 orang (18\%), dan masa pengabdian antara 11-15 tahun sejumlah 2 pustakawan (9\%). Sementara pustakawan yang memiliki masa kerja setara dengan 10 tahun atau kurang dari itu sejumlah 0 orang.

\section{Tingkat Kepercayaan Diri}

\begin{tabular}{cccc}
\multicolumn{4}{c}{ Tabel 5 Tingkat Kepercayaan Diri Pustakawan UII } \\
\hline No & Tingkat Kepercayaan Diri & Jumlah & Persentase (\%) \\
\hline 1 & Tinggi & 15 & 68 \\
\hline 2 & Sedang & 3 & 14 \\
3 & Rendah & 4 & 18 \\
\hline & Jumlah & 22 & 100 \\
\hline
\end{tabular}

Sumber: Data Primer $2016 \mathrm{~N}=22$

Pada Tabel 5 tampak bahwa tingkat kepercayaan diri Pustakawan UII berada pada posisi tingkat tinggi sebesar 68\% (15 orang), tingkat rendah sebesar 18\% (4 orang), dan posisi sedang 
sebesar $14 \%$ (3 orang).

\section{Tingkat Pengembangan Karir}

Tabel 6 Tingkat Pengembangan Karir Pustakawan UII

\begin{tabular}{cccc}
\hline No & Tingkat Pengembangan Karir & Jumlah & Persentase (\%) \\
\hline 1 & Tinggi & 8 & 36 \\
2 & Sedang & 11 & 50 \\
3 & Rendah & 3 & 14 \\
& Jumlah & 22 & 100 \\
\hline
\end{tabular}

Sumber: Data Primer $2016 \mathrm{~N}=22$

Pada Tabel 6 tampak bahwa tingkat pengembangan karir Pustakawan UII berada pada posisi tingkat sedang sebesar 50\% (11 orang), tingkat tinggi 36\% (8 orang), dan posisi rendah sebanyak $14 \%$ (3 orang).

\section{Uji Reliabiltas}

Kepercayaan Diri Pustakawan UII

\begin{tabular}{|c|c|c|l|l|}
\hline \multicolumn{6}{c|}{ Case Processing Summary } \\
\hline & $\mathrm{N}$ & $\%$ & & \\
\hline Valid & 22 & 100.0 & & \\
Cases Excluded & 0 & .0 & & \\
Total $^{\mathrm{a}}$ & 22 & 100.0 & & \\
\hline
\end{tabular}

a. Listwise deletion based on all variables in the procedure.

\section{Reliability Statistics}

\begin{tabular}{|c|c|}
\hline Cronbach's Alpha & N of Items \\
\hline .653 & 7 \\
\hline
\end{tabular}

Item-Total Statistics

\begin{tabular}{|c|c|c|c|c|}
\hline & $\begin{array}{l}\text { Scale Mean if } \\
\text { Item Deleted }\end{array}$ & $\begin{array}{c}\text { Scale Variance } \\
\text { if Item } \\
\text { Deleted }\end{array}$ & $\begin{array}{l}\text { Corrected } \\
\text { Item-Total } \\
\text { Correlation }\end{array}$ & $\begin{array}{c}\text { Cronbach's } \\
\text { Alpha } \\
\text { if Item } \\
\text { Deleted }\end{array}$ \\
\hline item 1 & 17.27 & 3.065 & .252 & .651 \\
\hline item2 & 16.23 & 2.946 & .237 & .665 \\
\hline item3 & 16.95 & 2.903 & .626 & .564 \\
\hline item4 & 17.05 & 2.903 & .471 & .589 \\
\hline item5 & 17.05 & 2.903 & .471 & .589 \\
\hline item6 & 17.27 & 2.874 & .270 & .654 \\
\hline item7 & 17.09 & 2.944 & .399 & .607 \\
\hline
\end{tabular}

Dari output gambar di atas, diketahui bahwa nilai Alpha sebesar 0,653 dimana angka hitungan 0,653 lebih besar yang apabila dibandingkan dengan nilai $r_{\text {tabel }}$ dengan nilai $\mathrm{N}=22$ (signifikansi kesalahan pada tingkat 5\%) adalah 0,423. Kesimpulannya nilai hitung (Alpha) $=0,653>r_{\text {tabel }}$ $=0,423$ artinya item-item pertanyaan kuisioner Kepercayaan Diri Pustakawan UII dapat dikatakan reliabel atau terpercaya sebagai alat pengumpul data dalam penelitian.

\section{Pengembangan Karir Pustakawan UII}

Case Processing Summary

\begin{tabular}{|cc|c|c|}
\hline & & $\mathrm{N}$ & $\%$ \\
\hline \multirow{3}{*}{ Cases } & Valid $^{*}$ Excluded $^{\mathrm{a}}$ & 22 & 100.0 \\
& Total $^{*}$ & 22 & .0 \\
& & 22 & 100.0 \\
\hline
\end{tabular}

a. Listwise deletion based on all variables in the procedure.

\begin{tabular}{|c|c|}
\hline \multicolumn{2}{c}{ Reliability Statistics } \\
\hline Cronbach's Alpha & N of Items \\
\hline .734 & 8 \\
\hline
\end{tabular}

Gambar di atas, tampak bahwa nilai Cronbach's Alpha sebesar 0,734 dimana angka hitungan 0,734 lebih besar yang apabila dipadankan dengan nilai $r_{\text {tabel }}$ dengan nilai $\mathrm{N}=22$ (signifikansi kesalahan pada tingkat 5\%) adalah 0,423. Kesimpulannya nilai hitung (Alpha) $=0,734>r_{\text {tabel }}=0,423$ artinya item-item pertanyaan kuisioner Pengembangan Karir Pustakawan UII dapat dikategorikan reliabel atau sohih sebagai instrumen riset.

\section{Uji Validitas}

Uji Validitas Kepercayaan Diri Pustakawan UII

Dari hasil hitungan correlations tersebut di atas dapat diketahui bahwa semua pertanyaan dalam kuisioner penelitian pada variabel tingkat kepercayaan diri pustakawan UII memiliki nilai antara 0,490 - 0,729. Angka-angka tersebut lebih besar dari $r_{\text {tabel }^{\prime}}$ Dimana nilai $r_{\text {tabel }}$ untuk $\mathrm{N}=22$ dengan tingkat kesalahan 5\% adalah 0,423. Kesimpulannya adalah semua item pertanyaan pada variabel ini dinyatakan valid. Untuk lebih memahamkan dapat ditampilkan rangkuman di bawah ini: 
Tabel 7 Hasil Uji Validitas Dimensi

Kepercayaan Diri Pustakawan UII

\begin{tabular}{cccc}
\hline $\begin{array}{c}\text { Nomor } \\
\text { Pertanyaan }\end{array}$ & $\mathbf{r}_{\mathbf{x y}}$ & $\mathbf{r}_{\text {tabel }}$ & Validitas \\
\hline 1 & 0,490 & 0,423 & Valid \\
\hline 2 & 0,513 & 0,423 & Valid \\
3 & 0,729 & 0,423 & Valid \\
\hline 4 & 0,634 & 0,423 & Valid \\
5 & 0.634 & 0,423 & Valid \\
\hline 6 & 0,542 & 0,423 & Valid \\
\hline 7 & 0,587 & 0,423 & Valid \\
\hline
\end{tabular}

Sumber: data Primer 2016, N = 22

Uji Validitas Pengembangan Karir Pustakawan

Dari hasil hitungan correlations tersebut di atas dapat diketahui bahwa dari semua pertanyaan dalam kuisioner penelitian pada variabel tingkat pengembangan karir pustakawan UII ada satu item yang nilainya di bawah $r_{\text {tabel }}$ yaitu item pertanyaan nomor 6 dengan skor 0,391 (tidak valid). Sedangkan item lainnya memiliki nilai di atas $r_{\text {tabel }}$ antara 0,425 - 0,790. Angka-angka tersebut lebih besar dari $r_{\text {tabel }}$. Dimana nilai $r_{\text {tabel }}$ untuk $\mathrm{N}=22$ dengan tingkat kesalahan $5 \%$ adalah 0,423 . Kesimpulannya adalah semua item pertanyaan pada variabel ini dinyatakan valid, kecuali item nomor 6 . Untuk dapat lebih memahaminya ditampilkan rangkuman di bawah ini:

Tabel 8 Hasil Uji Validitas Dimensi

Pengembangan Karir Pustakawan UII

\begin{tabular}{cccc}
\hline $\begin{array}{c}\text { Nomor } \\
\text { Pertanyaan }\end{array}$ & $\mathbf{r}_{\mathbf{x y}}$ & $\mathbf{r}_{\text {tabel }}$ & Validitas \\
\hline 1 & 0,587 & 0,423 & Valid \\
\hline 2 & 0,689 & 0,423 & Valid \\
3 & 0,790 & 0,423 & Valid \\
\hline 4 & 0,773 & 0,423 & Valid \\
5 & 0,723 & 0,423 & Valid \\
6 & 0,391 & 0,423 & Tidak Valid \\
7 & 0,441 & 0,423 & Valid \\
\hline 8 & 0,425 & 0,423 & Valid \\
\hline
\end{tabular}

Sumber: data Riset 2016, $N=22$

\section{Uji Korelasi}

Hubungan antar variabel selain dapat untuk mengetahui derajat/keeratan hubungan, dapat juga untuk mengetahui arah hubungan dua variabel numerik. Pada riset ini akan dicari korelasi antara kepercayaan diri pustakawan UII terhadap pengembangan karir pustakawan UII.

Dari hasil hitungan di atas diketahui bahwa antara Kepercayaan Diri Pustakawan UII (X) dengan Pengembangan Profesi Pustakawan UII (Y) nilai signifikansi 0,175>0,05 (0,175 lebih besar dari $0,05)$ yang berarti tidak ada korelasi yang signifikan antara variabel $\mathrm{X}$ dengan variabel $\mathrm{Y}$. Sementara tingkat korelasi antara variabel $X$ dengan variabel $Y$ terdapat hubungan sebesar $30 \%(0,300)$ dimana kriteria tingkat hubungan (koefisien korelasi antar variable berkisar antara \pm 0.00 sampai $\pm 1,00$ dengan rincian sebagai berikut:

1. 0,00 hingga 0,20 artinya: hampir tidak ada hubungan

2. 0,21 hingga 0,40 artinya : hubungan rendah

3. 0,41 hingga 0,60 artinya: hubungan sedang

4. 0,61 hingga 0,80 artinya: hubungan tinggi

5. 0,81 hingga 1,00 artinya hubungan sempurna

Dari data peneltian ini diperoleh hasil bahwa tingkat korelasi antara kepercayaan diri dengan pengembangan profesi pustakawan UII adalah sebesar $30 \%(0,300)$. Artinya pengaruh pengembangan karir pustakawan dari kepercayaan diri hanya sebesar $30 \%$ saja, sementara masih ada faktor diluar kepercayaan diri sebesar $70 \%$ yang mempengaruhi pengembangan karir pustakawan.

Berdasarkan hasil uji korelasi tersebut diatas dapat disimpulkan bahwa pada riset ini menolak hypothesis yang menyebutkan bahwa terdapat korelasi antara kepercayaan diri dengan pengembangan profesi pustakawan UII dalam menjalani profesinya.

\section{Uji Normalitas Data}


Uji normalitas data dimaksudkan untuk mengetahui apakah data riset berdistribusi normal atau tidak. Sebab dalam statistik parametrik distribusi data yang normal adalah suatu keharusan dan sebagai syarat mutlak yang wajib terpenuhi. Uji normalitas data pada riset ini memakai Uji

\section{Kolmogorov-Smirnov.}

Berdasarkan output hasil hitungan, ditemukan bahwa angka siginifikansi sebesar 0,991 lebih besar dari 0,05 , sehingga dapat disimpulkan bahwa uji data dalam penelitian ini terbukti normal.

\section{Pembahasan}

Dari hasil uji korelasi antara variabel kepercayaan diri (varabel $\mathrm{X}$ ) dengan variabel pengembangan profesi (variabel Y) pustakawan UII ditemukan hasil bahwa tingkat hubungan variabel $X$ dengan variabel $Y$ sebesar 30\%, artinya bahwa faktor yang mempengaruhi pengembangan profesi pustakawan bukan hanya faktor kepercayaan diri saja, akan tetapi masih ada banyak faktor lain yang mempengaruhinya. Faktor lain yang dimaksud antara lain: (1) adanya tugas ganda bagi pustakawan sehingga pekerjaan kepustakawanan hampir tidak tersentuh; (2) adanya program pelatihan dan peningkatan pendidikan yang lebih tinggi bagi pustakawan di bidang kepustakawanan; (3) adanya motivasi yang tinggi bagi pustakawan juga dapat mempengaruhi peningkatan profesi pustakawan; (4) lingkungan kerja yang kondusif; dan (5) adanya kepemimpinan profetik yang diberlakukan di lembaga dimana pustakawan mengembangkan profesinya. Masih ada sebagian pegawai yang menjalani tugas ganda yang disebabkan oleh terbatasnya tenaga kerja yang tersedia yang menyebabkan beberapa pegawai ada yang masih berperan ganda dalam menjalankan jabatan dan tugasnya. Pegawai yang memiliki peran ganda dalam menjalankan tanggung jawabnya tentu akan berdampak pada hasil yang diraih tidak optimal karena para pegawai hanya memiliki waktu yang terbatas dalam merampungkan pekerjaannya mengingat tugas yang overload tersebut. Dalam kondisi yang demikian, maka uraian tugas (job description) yang sudah ditetapkan dengan hasil kerja yang kurang maksimal, maka hal ini akan menjadi bahan evaluasi bagi manajemen perpustakaan. Perlu adanya perlakuan khusus bagi pegawai dalam memberikan motivasinya sehingga mereka akan mampu menjalankan fungsi dan tanggung jawabnya dengan baik sesuai uraian tugas yang telah ditentukan. Ketika masalah ini tidak dijalani maka akan berimplikasi pada menurunnya mutu kerja serta berkurangnya kualitas pelayanan kepada pemustaka/pelanggan yang selama ini sudah berhasil dengan baik. Pemberian motivasi dimaksudkan dalam rangka untuk memacu prestasi kerja pegawai sesuai dengan fungsi dan tugas masing-masing.

Para tenaga kependidikan (tendik) di lokasi penelitian ini, saat sekarang ini sedang digalakkan adanya pengembangan profesi melalui program pendidikan dan pelatihan ke tingkat yang lebih tinggi mulai jenjang Diploma sampai dengan tingkat doktor (S3). Kesempatan ini untuk mengikuti pengembangan profesi ini dilaksanakan secara selektif dan kompetitif. Tidak semua pegawai memiliki kesempatan yang sama, tergantung prestasi dan kemampuan para tendik. Para Pustakawan UII diberikan kesempatan untuk menempuah pendidikan formal ke jenjang yang lebih tinggi melalui tugas belajar dan atau izin belajar dari Rektor UII. Dalam Peraturan Rektor UII Nomor 13 tahun 2014 Pasal 1 ayat 4 menyebutkan bahwa, tugas belajar adalah penugasan yang diberikan oleh Rektor kepada Tenaga Kependidikan Tetap untuk melanjutkan pendidikan ke jenjang yang lebih tinggi atau yang setara di dalam atau di luar negeri, bukan atas biaya sendiri, dan meninggalkan tugas sehari-hari sebagai Tenaga Kependidikan Tetap UII. Pasal 1 ayat 5 menjelaskan bahwa izin belajar adalah izin yang diberikan oleh Rektor kepada 
Tenaga Kependidikan Tetap untuk melanjutkan pendidikan ke jenjang yang lebih tinggi atau yang setara di dalam negeri dengan biaya mandiri tanpa subsidi apapun dari UII. Perbedaan mendasar ayat 4 dan 5 tersebut adalah terletak pada lokasi belajar dan biaya studi. Pustakawan yang diberi tugas Rektor untuk studi lanjut boleh mengambil tempat pendidikan di dalam atau di luar negeri. Sementara peserta izin belajar hanya dapat mengambil tempat tugas belajar di dalam negeri. Biaya pendidikan bagi peserta tugas belajar sepenuhnya dibiayai oleh UII, dan bagi peserta yang mendapat izin belajar semua biaya pendidikan ditanggung oleh tenaga kependidikan yang bersangkutan. Motivasi individu dipengaruhi oleh dua faktor yaitu faktor intrinsik dan faktor ekstrinsik. Faktor intrinsik meliputi prestasi, pengakuan diri, sifat pekerjaan tanggung jawab dan pengembangan karir, sedangkan faktor ekstrinsik meliputi gaji, lingkungan kerja, hubungan kerja. Teori Herzberg juga menyampaikan bahwa kinerja dipengaruhi oleh faktor motivator yang dimanifestasikan pada keberhasilan, penghargaan, tanggung jawab, pekerjaan, dan pengembangan diri. Teori ini menjelaskan bahwa dengan perubahan intrinsik faktor kepuasan kerja dapat dimotivasi. Sedangkan faktor ekstrinsik hanya merupakan faktor yang bersifat pencegah terjadinya ketidakpuasan kerja.

Pengaruh lainnya adalah dari faktor kepemimpinan profetik sebagaimana yang dijelaskan dari hasil penelitian Sungadi (2011) bahwa variabel Kepemimpinan Profetik $\left(\mathrm{X}_{1}\right)$ dengan selang kepercayaan $a: 5 \%$ diperoleh harga $r$ : 0,737 dengan signifikansi 0,000. Berdasarkan hasil analisis ini maka dapat disimpulkan bahwa variabel kepemimpinan profetik $\left(X_{1}\right)$ berkorelasi positif terhadap variabel produktivitas kerja ( $Y$ ). Artinya kepemimpinan profetik berkontribusi sebesar 73,7\% terhadap produktivitas kerja pustakawan UII, sehingga apabila produktivitas tinggi maka profesi bagi tenaga fungsional pustakawan juga akan berkembang pula. Masih hasil penelitian Sungadi (2011) pengaruh lain dari produktivitas kerja adalah motivasi kerja memberikan kontribusi sebesar $82,6 \%$. Angka $73,7 \%$ dan $82,6 \%$ tersebut dapat dikategorikan pengaruh yang tinggi terhadap produktivitas kerja.

\section{Kesimpulan Dan Saran \\ Kesimpulan}

Berdasarkan analisis dan olah data dapat diambil kesimpulan bahwa:

1. Tingkat kepercayaan diri Pustakawan UII dalam menjalani profesi pustakawan berada pada posisi tinggi sebesar $68 \%$.

2. Tingkat pengembangan karir Pustakawan UII berada pada posisi tingkat sedang sebesar $50 \%$.

3. Berdasarkan hasil uji korelasi, dalam penelitian dapat disimpulkan bahwa pada riset ini menolak hypothesis yang menyebutkan bahwa terdapat hubungan antara kepercayaan diri dengan pengembangan profesi pustakawan UII dalam menjalani profesinya.

4. Dari peneltian ini diperoleh hasil bahwa tingkat korelasi antara kepercayaan diri dengan pengembangan profesi pustakawan UII adalah sebesar 30\% (0,300). Artinya pengaruh pengembangan karir pustakawan dari kepercayaan diri hanya sebesar 30\% saja, sementara masih ada faktor diluar kepercayaan diri sebesar $70 \%$ yang mempengaruhi pengembangan karir pustakawan. Faktor lain di luar kepercayaan diri tersebut antara lain: (1) adanya tugas ganda bagi pustakawan sehingga pekerjaan kepustakawanan hampir tidak tersentuh; (2) adanya program pelatihan dan peningkatan pendidikan yang lebih tinggi bagi pustakawan di bidang kepustakawanan; (3) adanya motivasi yang tinggi bagi pustakawan juga dapat mempengaruhi peningkatan profesi pustakawan; (4) lingkungan kerja 
Analisis Pengaruh Kepercayaan Diri ... (Sungadi)

yang kondusif; dan (5) adanya kepemimpinan profetik yang diberlakukan di lembaga dimana pustakawan mengembangkan profesinya.

\section{Saran}

Disarankan bagi peneliti berikutnya, agar melibatkan pustakawan di luarUll dengan temayang sama, misalnya melibatkan pustakawan perguruan tinggi swasta di DIY yang telah memberlakukan tenaga perpustakaan sebagai tenaga fungsional pustakawan. Atau mengambil subjek penelitian di perguruan tinggi Islam di DIY baik perguruan tinggi negeri atau swasta.

\section{Daftar Pustaka}

Andriyani, H. 2001. Hubungan Antara kepercayaan Diri, Kemandirian dengan Prestasi Atlet Pencak Silat. Skripsi (tidak diterbitkan). Yogyakarta: Fakultas Psikologi UII.

De Angelis, B. 2002. Percaya Diri : Sumber Sukses dan Kemandirian. Jakarta: PT Gramedia Pustaka Utama.

Eliot, Charles William. 2007. http://www.usu.edu/ campaign/colleges/library.cfm. Diakses tanggal 5 November 2015

Guilford, J.P. 1959. Personality. New York: Mc. Graw HillBook Company. Inc.

Indonesia, Peraturan Menteri Pendayagunaan Aparatur Negara dan Reformasi Birokrasi Republik Indonesia Nomor 9 Tahun 2014 tentang Jabatan Fungsional Pustakawan dan Angka Kreditnya, (Jakarta: Kemenpan \& RB, 2014), Bab I, Pasal 1.

Lauster, P. 1978. Tes Kepribadian (diterjemahkan oleh D.H Gulo). Jakarta: PT Gaya Media Pratama.

Lyn, Robinson \& Audrone Glosiene. 2007. New Information Perspectives. Aslib Proceedings: 59 (4): 462-474

Mallawa, Suharyanto "Pengembangan Karier Pustakawan: Alih Jalur Pustakawan Terampil Ke Pustakawan Tingkat Ahli," diakses 22 Desember
2016, https://www.academia.edu/5451378/ Pengembangan_karier_pustakawan_ alih_jalur_pusatakawan_terampil_ke_ pustakawan_tingkat_ahli.

Mumiatiek, J. 2001. Hubungan Antara Kepercayaan Diri dengan Somatisasi. Skripsi (tidak diterbitkan). Yogyakarta: Fakultas Psikologi UII.

Perpusnas RI. 2015. Peraturan Kepala Perpustakaan Nasional Republik Indonesia Nomor 11 Tahun 2015 Tentang Petunjuk Teknis Jabatan Fungsional Pustakawan Dan Angka Kreditnya. Jakarta: Perpusnas RI.

Rakhmat, J. 1985. Psikologi Komunikasi. Bandung: Remadja Karya.

Raudhah, 2002. Persepsi Terhadap Suasana Rumah dan Kepercayaan Diri pada Remaja. Skripsi (tidak diterbitkan). Yogyakarta: Fakultas Psikologi UII.

Sudarsono, Blasius. 2010. Pengembangan Profesi Pustakawan. Jakarta: Media Pustakawan

Universitas Islam Indonesia. 2014. Peraturan UII Nomor 13 tahun 2014 tentang Tugas Belajar Bagi Tenaga Kependidikan Tetap Universitas Islam Indonesia. Yogyakarta: UII.

Universitas Islam Indonesia. 1993. Inpassing Pustakawan UII, Surat Keputusan Penetapan Angka Kredit Berdasarkan Inpassing. Yogyakarta: UII,

Walgito, B. 1993. Hubungan Persepsi Mengenai Sikap Orang Tua dengan Konsep Diri dan Harga Diri pada Siswa sekolah Menengah Atas di Propinsi Jateng. Disertasi. (Tidak diterbitkan). Yogyakarta: Fakultas Psikologi UGM.

Wibawati, Ika Pratiwi. 2003. Hubungan Antara Kepercayaan Diri Dengan Aktualisasi Diri Pada Remaja Akhir. Skripsi (tidak diterbitkan). Yogyakarta: Fakultas Psikologi UII.

Yusni, MA. 2002. Hubungan Antara Kepercayaan Diri dengan Prestasi Kerja pada Perawat. Skripsi (tidak diterbitkan). Yogyakarta: Fakultas Psikologi UII. 